\title{
Pengaruh Pengalaman Lapangan Industri terhadap Kesiapan Kerja Mahasiswa Program Studi D4 Manajemen Perhotelan Angkatan 2015 Universitas Negeri Padang
}

\author{
Yulita Sari ${ }^{1}$, Youmil Abrian ${ }^{2}$ \\ ${ }^{1}$ Universitas Negeri Padang \\ ${ }^{2}$ Universitas Negeri Padang \\ email : yulitachan.ys@gmai.com
}

\begin{abstract}
Based on this research, the writer recommend the lecturer that concerned with internship programe to guide the students with their choice of where to apply the internship programme which is corresponding to their interest and skill, so that they can be more confident of the skill that they have and develop it. The purpose of the research is to analyze the influence of Internship on Work Readiness to the students which is already did the first and the second internship especially for the 2015 class of Hospitality Management in Padang State University.

The kind of the research that used is quantitative descriptive and causal associatitive approach to view the influence of Internship (X) on Work Readiness (Y). The population and sample of this research are the students of Hospitality Management class 2015 of Padang State University. The technique of the data analyze that used is descriptive analysis technique by SPSS 16.00 Version.

Based on the research, the results are as follows: (1) Internship is in the good category $(52,73 \%),(2)$ Work Readiness is in the good category (56,37\%), (3) From simple linear resgresion hypothesis the results is F 1.515 with sig. $0,142<0,05$, so the intership variabel can explain the work readiness significantly, with an $\mathrm{R}$ score value as much 0,523 . This means that intership had influence on work readiness as much $52,3 \%$, while $47,7 \%$ because of another factor. Therefore the result of it is 9,245 with significant level is $0,000<0,05$, so there is significant relationship from both variabel. The regression coefficient as much 0,882 with significant value at $0,000<0,05$. It is mean that every 1 unit of the internship influence will gain 0,882 unit of work readiness. Based on this research, the writer recommend the lecturer that concerned with internship program to guide the students with their choice of where to apply the internship programme which is corresponding to their interest and skill, so that they can be more confident of the skill that they have and develop it.
\end{abstract}

Key words : Internship, Work Readiness

\section{PENDAHULUAN}

Pendidikan adalah sarana untuk meningkatkan kualitas SDM. Pendidikan dapat membuka wawasan individu untuk mengetahui banyak hal baru. Pendidikan yang berkualitas akan menghasilkan kualitas SDM yang berkompetensi dan dapat bersaing dalam dunia lapangan kerja. Oleh sebab itu pentingnya pendidikan diharapkan dapat meningkatkan potensi mahasiswa dalam masa pembelajaran dan meningkatkan kualitas lulusan dalam mencapai tujuan umum pendidikan. 
Pada saat sekarang ini kompetensi persaingan dalam dunia pasar kerja semakin ketat, sehingga menuntut SDM harus memiliki kompetensi dan keahlian tertentu yang sesuai dengan kualifikasi yang diinginkan perusahaan tempat melamar pekerjaan.

Data yang penulis dapatkan pada Badan Pusat Statistik memperlihatkan pada Agustus 2017 terjadi peningkatan pengangguran terbuka dengan pendidikan akhir merupakan lulusan universitas yang terjadi di Sumatera Barat dari 6,78 \% pada Agustus 2017 menjadi 9,56 \% pada Agustus 2018 [2].

Berdasarkan pra penelitian yang dilakukan peneliti pada tanggal 28 Agustus 2019, gejala yang terjadi pada kesiapan kerja alumni Program Studi D4 Manajemen Perhotelan angkatan 2014 dari 30 alumni adalah 50\% alumni bekerja di hotel setelah lulus, 30\% alumni bekerja tidak sesuai dengan kompetensi keahlian yang dimiliki, $20 \%$ alumni masih belum mendapatkan pekerjaan. Data tersebut penulis dapat dari pertanyaan yang penulis berikan kepada 30 responden yaitu yang merupakan alumni manajemen perhotelan angkatan 2014, penulis bertanya dengan pesan melalui salah satu sosial media yaitu WhatsApp kepada responden. Data nomor WhatsApp 30 responden tersebut penulis dapatkan dari salah satu alumni manajemen perhotelan 2014 yang bernama Yandi Eka Putra S.ST. Dari 30 alumni tersebut didapat data 15 orang bekerja di hotel setelah lulus dari Universitas Negeri Padang, 9 orang tidak bekerja di hotel, dan 6 orang masih belum mendapatkan pekerjaan. Selanjutnya, hasil persentase didapatkan dengan cara mengalikan jumlah alumni sesuai dengan kategori pekerjaanya dengan 3.33 agar dapat berjumlah $100 \%$.

Adapun tabel mengenai gejala yang terjadi pada kesiapan kerja mahasiswa Program Studi D4 Manajemen Perhotelan angkatan 2014 dari 30 mahasiswa adalah sebagai berikut :

Tabel 1. Gejala pada kesiapan kerja mahasiswa Manajemen Perhotelan angkatan 2014

\begin{tabular}{|l|l|}
\hline Gejala & Persentase \\
\hline Alumni bekerja di hotel & $50 \%$ \\
$\begin{array}{l}\text { Alumni tidak bekerja di } \\
\text { hotel }\end{array}$ & $30 \%$ \\
\hline $\begin{array}{l}\text { Alumni masih belum } \\
\text { mendapatkan pekerjaan }\end{array}$ & $20 \%$ \\
\hline Jumlah & $\mathbf{1 0 0} \%$ \\
\hline
\end{tabular}

Dari tabel tersebut dapat dilihat bahwa kesiapan kerja mahasiswa Program Studi D4 Manajemen Perhotelan masih belum optimal, terlihat dari 30\% alumni tidak bekerja di hotel, yang artinya ia tidak bekerja sesuai dengan kompetensi yang pernah ia pelajari.

Oleh karena itu, mahasiswa Program Studi D4 Manajemen Perhotelan seharusnya lebih dapat menguasai segala pengetahuan yang telah mereka pelajari sehingga mereka dapat memiliki kompetensi yang sesuai dengan jurusan saat di universitas.

Tujuan penelitian adalah menganalisa pengaruh PLI terhadap kesiapan kerja mahasiswa jurusan Manajemen Perhotelan angkatan 2015 Universitas Negeri Padang ditinjau dari variable X yaitu, pendidikan dan pengembangan SDM, pemantapan dan pematangan hasil belajar, keterampilan saat bekerja, pembentukan sikap saat bekerja, serta keterampilan dan kemampuan yang sesuai dengan bidangnya. dan variabel Y dengan 6 indikator yaitu, keterampilan, kecerdasan, kemampuan dan minat, motivasi, kematangan, serta kesehatan.

\section{METODOLOGI}

Penulis menggunakan penelitian kuantitatif dengan pendekatan asosiatif kausal. Populasi yang penulis gunakan adalah mahasiswa Program Studi D4 Manajemen Perhotelan 2015 Universitas Negeri Padang 
yang telah mengikuti Pengalaman Lapangan Industri 1 dan 2, yang berjumlah 123 orang. Teknik simple random sampling digunakan dalam penelitian ini, dimana teknik menentukan populasi mempunyai anggota atau unsur yang tidak homogen tanpa memperhatikan strata [6]. Responden dalam penelitian ini adalah Mahasiswa Manajemen Perhotelan 2015 Universitas Negeri Padang.

Untuk mengukur besarnya sampel maka digunakan rumus Slovin dan diperoleh hasil sampel yaitu 55, 15 yang dibulatkan menjadi 55. Rumus yang dipakai dalam mendiskripsikan data adalah rata-rata ideal (Mi) dan std deviasi (Sdi) [4]. Angket yang akan disebarkan ,diuji validitas dan reliabel terlebih dahulu. Analisis regresi sederhana digunakan sebagai alat ukure dalam pengujiasn hipotesis di penelitian ini.

\section{HASIL DAN PEMBAHASAN}

\section{Pengalaman Lapangan Industri $(X)$}

Data hasil skor Variabel Pengalaman Lapangan Industri (X) dapat dilihat sebagai berikut

Tabel 2. Skor Jawaban Responden Tentang Pengalaman Lapangan Industri

\begin{tabular}{|c|c|c|c|}
\hline Kategori & Rentang Skor & $\mathbf{F}$ & $\%$ \\
\hline Sangat baik & $\geq 96$ & 7 & 12,73 \\
\hline Baik & $80-<96$ & 29 & 52,73 \\
\hline Cukup & $64-<80$ & 19 & 34,54 \\
\hline Buruk & $48-<64$ & 0 & 0 \\
\hline Sangat buruk & $<48$ & 0 & 0 \\
\hline \multicolumn{2}{|c|}{ Total } & 55 & 100 \\
\hline
\end{tabular}

Sumber: Microsoft Excel, 2019

Dari data di atas tentang Pengalaman Lapangan Industri 12,73\% responden masuk kategori sangat baik, 52,73\% masuk kategori baik, 34,54\% responden masuk kategori cukup baik, 0 responden menunjukkan kategori buruk, dan 0 termasuk kategori sangat buruk. Sehingga dapat disimpulkan bahwa responden tentang Pengalaman Lapangan Industri adalah kategori baik.

2. Variabel Kesiapan Kerja (Y)

Untuk melihat hasil penilaian variabel kesiapan kerja dapat dilihat :

Tabel 22. Klasifikasi Responden Tentang Kesiapan Kerja

\begin{tabular}{|l|l|l|l|}
\hline Kategori & Rentang skor & F & $\%$ \\
\hline Sangat baik & $\geq 115,95$ & 6 & 10,90 \\
\hline Baik & $\mathbf{9 6 , 6 5}-<\mathbf{1 1 5 , 9 5}$ & $\mathbf{3 1}$ & $\mathbf{5 6 , 3 7}$ \\
\hline Cukup & $77,35-<96,65$ & 18 & 32,73 \\
\hline Buruk & $58,05-<77,35$ & 0 & 0 \\
\hline Sangat buruk & $<58,05$ & 0 & 0 \\
\hline Jumlah & 55 & 100 \\
\hline
\end{tabular}

Sumber: Microsoft Excel, 2019

Dari dara diatas, 10,90\% responden masuk kategori sangat baik, 56,37\% masuk kategori baik, $32,73 \%$ responden masuk kategori cukup baik, 0 responden menunjukkan kategori buruk, dan 0 masuk kategori sangat buruk. Dapat disimpulkan bahwa responden tentang Kesiapan Kerja adalah baik.

\section{Uji Persyaratan Analisis}

\section{a. Uji Normalitas}

Diperoleh Asymp Sig untuk variabel pengalaman lapangan industri adalah 403 dan untuk kesiapan kerja adalah 376 dengan nilai > 0.05 maka dapat dikatakan bahwa kedua data terdistribusi normal. 


\section{b. Uji Homogenitas}

Hasil analisis uji homogenitas nilai Signifikansi sebesar 0,052 dengan signifikansi > 0,05. Dapat diambil kesimpulan bahwa data berasal dari populasi yang mempunyai varians yang sama atau data bersifat homogen.

\section{c. Uji Linearitas}

Dari uji linearitas diperoleh nilai sig 0,142 dengan signifikansi $\geq 0,05$. maka dapat disimpulkan terdapat hubungan yang linear secara signifikan antara variabel pengaruh lapangan industri (X) dengan kesiapan kerja (Y).

\section{Uji Hipotesis}

\section{Uji Regresi Linear Sederhana}

Berdasarkan pada uji regresi linier sederhana, didadapatkan nilai F 85,467 dimana sig. $\quad 0,000 \leq$ 0,05 dan didapatkan nilai t 9,245 dengan sig. 0,000<0,05, artinya variabel pengalaman lapangan industri berpengaruh terhadap variabel kesiapan kerja.

selanjutnya diperoleh koefisien regresi sebesar 0,882 dengan nilai sig. $0.000<0.05$. Artinya setiap peningkatan sebesar 1 satuan pengaruh lapangan industri meningkatkan 0,095 satuan kesiapan kerja.

\section{Tabel 40. Koefisien Determinasi (R square)}

\section{Model Summary}

\begin{tabular}{|l|r|r|r|r|}
\hline Model & R & R Square & Adjusted R Square & Std. Error of the Estimate \\
\hline 1 & $.723^{\mathrm{a}}$ & .523 & .514 & 6.60778 \\
\hline
\end{tabular}

a Predictors: (Constant), TX

\section{Sumber: Hasil Olahan SPSS versi 16.00}

Dari data di atas, diperoleh nilai $\mathrm{R}$ square $=0,523$ artinya kontribusi atau pengaruh variabel pengalaman lapangan industri terhadap kesiapan kerja adalah 52,3\%, sedangkan 47,7\% ditentukan faktor lain.

\section{PEMBAHASAN}

Hasil penelitian menyatakan bahwa pengalaman lapangan industri berada pada kategori baik (72,73\%), dengan demikian mayoritas mahasiswa menyatakan bahwa PLI yang mereka laksanakan berjalan dengan baik serta sesuai dengan apa yang mereka harapkan. Mayoritas mahasiswa mendapatkan nilai yang baik dan supervisor di industri memberikan banyak bantuan dalam pelaksanaan lapangan industri mahasiswa. Pengawasan supervisor yang baik dari supervisor akan dapat membantu meningkatkan kinerja karyawan [1]. Sedangkan variable kesiapan kerja juga berada pada kategori baik $(56,37 \%)$, hal I mayoritas menunjukan bahwa Sebagian besar mahasiswa memiliki kesiapan untuk memasuki dunia kerja.

Uji hipotesis dengan analisis regresi, pelaksanaan Pengalaman Lapangan Industri, berpengaruh signifikan terhadap kesiapan kerja mahasiswa Manajemen Perhotelan, dengan kontribusi pengaruh sebesar 52,3\%. Hal ini menyatakan bahwa PLI yang dilaksanakan oleh mahasiswa berperan besar dalam membantu kesiapan mahasiswa tersebut untuk memasuki dunia kerja . Dengan mengikuti praktek magang mahasiswa akan lebih percaya diri dalam memasuki dunia kerja [3]. 


\section{KESIMPULAN}

\section{A. Kesimpulan}

Pengaruh Pengalaman Lapangan Industri terhadap Kesiapan Kerja Mahasiswa Program Studi D4 Manajemen Perhotelan Angkatan 2015 Universitas Negeri Padang, dapat disimpulkan sebagai berikut:

1. Pengalaman Lapangan Industri pada mahasiswa Manajemen Perhotelan angkatan 2015 Universitas Negeri Padang menunjukkan secara keseluruhan dengan nilai persentase sebesar 52,73\%. Termasuk kategori baik. Kesiapan Kerja pada mahasiswa Manajemen Perhotelan angkatan 2015 Universitas Negeri Padang menunjukkan secara keseluruhan dengan nilai persentase sebesar 56,37\% dapat dikategorikan baik.

2. Terdapat pengaruh signifikan antara Pengalaman Lapangan Industri terhadap Kesiapan Kerja mahasiswa Manajemen Perhotelan angkatan 2015 Universitas Negeri Padang dengan nilai R Square yaitu 0,523 . Artinya pengaruh variabel X terhadap variabel $\mathrm{Y}$ sebesar 52,3 \%, sedangkan 47,7\% ditentukan oleh faktor lain.

\section{DAFTAR PUSTAKA}

[1] M. Arman and K. Kasmita, "Pengaruh Pengawasan Supervisor Di Room Division Terhadap Kinerja Karyawan Hotel Axana Padang," J. Pendidik. Teknol. Kejuru., vol. 1, no. 4, pp. 161-166, 2018, doi: 10.24036/jptk.v1i4.2723.

[2] Berita Resmi Statistik BPS. (2018). Tingkat Pengangguran Terbuka (TPT). Diunduh dari www.bps.go.id pada tanggal 23 Juli 2019.

[3] Effirisanti, Yulia. 2015. "Pembelajaran Berbasis Proyek Melalui Program Magang Sebagai Upaya Peningkatan Soft Skill Mahasiswa". Ejournal.Stiedwantara, Vol.10,April.

[4] Arikunto, S. (2017). Pengembangan Instrumen Penelitian dan Penilaian Program. Yogyakarta: Pustaka Pelajar.

[5] Sugiyono. (2017). Metode Penelitian Kuantitatif, Kualitatif, dan R\&D. Bandung : Alfabeta, CV

[6] Darmadi, Hamid. (2011). Metode Penelitian Pendidikan. Bandung: Alfabeta.

[7] Endah Rahayu. (2011). Pengaruh Kerja Praktek Industri dan Minat Kerja terhadap Kesiapan Kerja Siswa Kelas XII SMK YPKK 2 Sleman Tahun Ajaran 2009/2010. Skripsi: FISE UNY. 